http://heanoti.com/index.php/hn

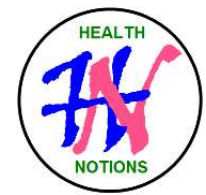

RESEARCH ARTICLE

URL of this article: http://heanoti.com/index.php/hn/article/view/hn50101

\title{
The Effect of Service Quality and Maternal Satisfaction of Children Under Five on the Behavior of Mothers Visiting "Posyandu"
}

\author{
Agung Suharto ${ }^{1(\mathrm{CA})}$, Budi Joko Santosa ${ }^{2}$, K. Kasiati ${ }^{3}$ \\ ${ }^{1(\mathrm{CA})}$ Department of Midwifery, Poltekkes Kemenkes Surabaya, Indonesia; agungsuharto14@gmail.com \\ (Corresponding Author) \\ ${ }^{2}$ Department of Midwifery, Poltekkes Kemenkes Surabaya, Indonesia; santosabudijoko@yahoo.co.id \\ ${ }^{3}$ Department of Midwifery, Poltekkes Kemenkes Surabaya, Indonesia; kasiatitaufik@gmail.com
}

\begin{abstract}
Background: "Posyandu" is a means for the community to obtain basic health services which includes five main "posyandu" activities, including: maternal and child health, family planning, nutrition, immunization and overcoming diarrhea. In terms of quantity, the development of the number of posyandu is very encouraging, because the ratio of posyandu to village is 3.51 "posyandu". This study aims to determine the effect of service quality and maternal satisfaction of children under five on the behavior of mothers visiting "posyandu". Methods: The design of this research was cross sectional. Population was 100 and sample was 80 people. Independent variable were the quality of service and satisfaction and dependent variable was the behavior (frequency) of visiting the "posyandu". Data analysis was done by: descriptive analysis, and logistic regression. Results: The most of respondents said the quality of service was good as many as $56.3 \%$ and a small proportion of respondents said the quality of service was sufficient as much as $8.8 \%$. Most of the respondents said that the level of satisfaction was satisfied as much as 55\% and a small proportion of respondents said the level of satisfaction was satisfied as much as $6.3 \%$. Most of the $\mathrm{h}$ good behavior was $71.3 \%$ and a small proportion of: less than $2.5 \%$. Obtained a significant effect of service quality on the behavior of mothers under five visiting "posyandu" ( $\mathrm{p}$-value $=0.005)$ and there was a significant effect of satisfaction with the behavior of mothers under five visiting "posyandu" (p-value $=0.011)$. Conclusion: the quality of service and satisfaction of mothers under five have an effect on the behavior of mothers visiting "posyandu".
\end{abstract}

Keywords: quality; satisfaction; behavior; "posyandu"

\section{INTRODUCTION}

\section{Background}

Health service is every effort carried out individually or jointly in an organization to maintain and improve health, prevent and cure diseases and restore health of individuals, families, groups and / or communities. Health services have an important role in increasing the degree of public health in the fields of promotion, preventive curative and rehabilitative ${ }^{(1)}$. Health development is an integral part of national development in realizing an optimal public health degree. In order to realize this, the direction of health development policies set out in the 2015-2019 Medium-Term Development Plan for the Health Sector, which refers to three important things, namely: Strengthening Primary Health Care, Application of the Sustainable Service Approach, and Health Risk-Based Interventions where the three things are empowerment efforts for the community. One form of community empowerment efforts in the health sector is to foster and develop Community-Based Health Efforts through the posyandu program $^{(2)}$.

"Posyandu" is a means for the community to obtain basic health services which includes five main posyandu activities, including: Maternal and Child Health, Family Planning, nutrition, immunization and overcoming diarrhea. In terms of quantity, the development of the number of posyandu is very encouraging, because the ratio of posyandu to village is 3.51 "posyandu". However, when viewed from the quality aspect, it was found that the number of posyandu service utilization by the community was still not running optimally. 
This can be seen from the activeness of parents in monitoring the growth and development of their children at the "posyandu" (3).

Based on the results of the Basic Health Research in 2018, data was obtained which showed that in Indonesia the number of posyandu utilization had decreased in 2018 (65.6\%) compared to 2017 (76\%), while the target to be achieved based on the 2015 Ministry of Health Strategic Plan target is $85 \%$. The low utilization rate of posyandu by the community is influenced by the behavior of the toddler's parents in utilizing posyandu services ${ }^{(4)}$.

\section{Purpose}

This study aims to determine the effect of service quality and maternal satisfaction of children under five on the behavior of mothers visiting "posyandu".

\section{METHODS}

The design of this research was cross sectional. The population in this study was 100 people and the sample size was 80 people, selected using simple random sampling. The independent variable were the quality of service and satisfaction of the mothers of the children under five, while the dependent variable was the behavior of mothers under five visiting the "posyandu". Data were collected through interview by visiting mothers, because it was still a COVID-19 pandemic. Data were analyzed using descriptive analysis and logistic regression ${ }^{(5)}$. The descriptive analysis was divided into 3 groups, namely enough, good and very good, by means of the total score of each research variable divided into 3 groups ${ }^{(6)}$.

\section{RESULTS}

\section{Age, Education and Occupation of Mothers}

Most of the respondents were 21-25 years old (55\%), secondary education (57.5\%) and working as housewives (52.4\%). A small proportion of respondents aged 31-35 years (11.2\%), highly educated (11.2\%) and working as civil servants $(5 \%)$.

Table 1. Distribution of respondents' age, education and occupation

\begin{tabular}{ccc}
\hline Age (year) & Frequency & Percentage \\
\hline $16-20$ & 12 & 15 \\
$21-25$ & 44 & 55 \\
$26-30$ & 15 & 18.8 \\
$31-35$ & 9 & 11.2 \\
\hline Education & Frequency & Percentage \\
\hline Primary & 25 & 31,3 \\
Second & 46 & 57,5 \\
High & 9 & 11,2 \\
\hline Profession & Frequency & Percentage \\
\hline Civil servants & 4 & 13.8 \\
Farmers, & 11 & 28.8 \\
Private sector & 23 & 52.4 \\
Housewives & 42 &
\end{tabular}

\section{Description of Variables}

Table 2. The distribution of service quality levels of respondents

\begin{tabular}{ccc}
\hline Service quality levels & Frequency & Percentage \\
\hline Enough (0-42) & 7 & 8.8 \\
Good (43-84) & 45 & 56.2 \\
Very good (85-125) & 28 & 35 \\
\hline Total & 80 & 100 \\
\hline
\end{tabular}

Based on table 2, it was found that the majority of respondents said the quality of service was good $(56.2 \%)$ and a small proportion of respondents said the quality of service was sufficient $(8.8 \%)$. 
Table 3. The distribution of satisfaction levels of respondents

\begin{tabular}{ccc}
\hline Satisfaction levels & Frequency & Percentage \\
\hline Enough (0-34) & 5 & 6.2 \\
Satisfied (35-68) & 44 & 55 \\
Very satisfied (69-100) & 31 & 38.8 \\
\hline Total & 80 & 100 \\
\hline
\end{tabular}

Based on table 3, it was found that the majority of respondents said the level of satisfaction was satisfied as much as $44(55 \%)$ and a small proportion of respondents said the level of satisfaction was enough $(6.2 \%)$.

Table 4. The distribution of behavior of respondents

\begin{tabular}{ccc}
\hline Behavior levels & Frequency & Percentage \\
\hline Less (1-4) & 2 & 2.4 \\
Enough (5-8) & 21 & 26.3 \\
Good (9-12) & 57 & 71.3 \\
\hline Total & 80 & 100 \\
\hline
\end{tabular}

Based on table 4, it was found that the most of respondents had good behavior $(71.3 \%)$ and a small proportion of respondents were in the less category $(2.4 \%)$.

\section{The Effect of the Quality and Satisfaction of Mothers Under Five on Mother Behavior Visiting "Posyandu"}

To determine the effect of the quality and satisfaction of mothers under five on visiting behavior at the posyandu, a logistic regression statistical analysis was carried out with the following results:

Table 5. Model fitting information

\begin{tabular}{ccccc}
\hline Model & $-2 \log$ likelihood & Chi-square & df & Sig. \\
\hline Intercept only & 41.661 & & & \\
Final & 23.442 & 18.219 & 3 & 0.000 \\
\hline
\end{tabular}

Model fitting information -2log ikelihood gets a Chi square value of 18.219 and a significance level of 0.00 .

Table 6. Goodness-of-fit

\begin{tabular}{cccc}
\hline & Chi-Square & Df & Sig. \\
\hline Pearson & 6.401 & 11 & 0.845 \\
Deviance & 7.557 & 11 & 0.752 \\
\hline
\end{tabular}

Goodness of Fit shows the model suitability test with person quality data of 6.401 with a significance of 0.845 and this is in accordance with the empirical data model or the model is feasible to use.

It was found that the significant effect of service quality on behavior was 0.005 and the satisfaction of mothers under five to the behavior of mothers under five visiting posyand $u$ was 0.011 .

Table 7. Parameter estimates

\begin{tabular}{|c|c|c|c|c|c|c|c|c|}
\hline & & \multirow[t]{2}{*}{ Estimate } & \multirow[t]{2}{*}{ Std. Error } & \multirow[t]{2}{*}{ Wald } & \multirow[t]{2}{*}{ df } & \multirow[t]{2}{*}{ Sig. } & \multicolumn{2}{|c|}{$\begin{array}{l}95 \% \text { Confidence } \\
\text { Interval }\end{array}$} \\
\hline & & & & & & & $\begin{array}{l}\text { Lower } \\
\text { Bound }\end{array}$ & $\begin{array}{l}\text { Upper } \\
\text { Bound }\end{array}$ \\
\hline \multirow{2}{*}{ Threshold } & {$[$ Behavior $=1]$} & -6.681 & 1.597 & 17.510 & 1 & 0.000 & -9.810 & -3.551 \\
\hline & {$[$ Behavior $=2]$} & -3.500 & 1.330 & 6.922 & 1 & 0.009 & -6.108 & -.893 \\
\hline \multirow{4}{*}{ Location } & Satisfaction & -1.397 & 0.548 & 6.498 & 1 & 0.011 & -2.471 & -.323 \\
\hline & [Quality=1] & -0.959 & 0.858 & 1.249 & 1 & 0.264 & -2.641 & 0.723 \\
\hline & [Quality $=2]$ & 1.755 & 0.621 & 7.973 & 1 & 0.005 & 0.537 & 2.973 \\
\hline & {$[$ Quality $=3]$} & $0^{\mathrm{a}}$ & 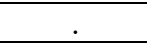 &. & 0 &. &. &. \\
\hline
\end{tabular}




\section{DISCUSSION}

The distribution of the quality level of the research respondents mostly stated that it was good. The quality of public services is an important component that must be considered in public services. The term public service quality cannot of course be separated from the perception of quality. Some examples of definitions of quality are: (1) Conformity with requirements; (2) Fit for use; (3) Continuous improvement; (4) Free from damage / defects; (5) Meeting customer needs from the beginning and at any time; (6) Doing everything right; (7) something that can make customers happy ${ }^{(7)}$.

Service quality is the service provided to customers in accordance with service standards that have been standardized in providing services as a good service standardization. Meanwhile, the quality of public services is a dynamic condition related to products, services, people, processes, and the environment where the quality assessment is determined at the time the provision of public services occurs ${ }^{(8)}$.

In the distribution of satisfaction levels, most of the research respondents said they were satisfied Of course, patient satisfaction is inseparable from each of the dimensions of satisfaction in dental and oral health services. The dimensions include, 1) Satisfaction of research respondents with the technical competence of health services (Guarantee), 2) Satisfaction of research respondents on the effectiveness of health services, 3) Satisfaction of research respondents on the efficiency of health services (Responsiveness), 4) Satisfaction of research respondents with comfort of health services (Physical appearance), and 5) Satisfaction of research respondents with human relations ${ }^{(9)}$. This is supported by the research of Nostib (2013) which states that in assessing the performance of health service providers there are two elements that need to be considered, namely technical media and interpersonal relationships. This includes explaining and providing information to the patient about his disease and deciding with the patient what to do with him $^{(10)}$.

Research by Bata et.al. (2013) which states that there is a significant relationship between physical appearance and patient satisfaction. Other research from Susmaneli and Triana (2014) also shows that there is a positive and significant influence on the comfort dimension (physical appearance) on patient satisfaction with one of the direct evidence available, namely comfort in the service room and waiting room. To apply good relations between individuals or between groups, an understanding of the basic principles of human relations is required. There are 10 basic principles of human relations with the term "The Ten Principal of Human Relations" which can be used to develop human relationships. The ten main principles are as follows: 1) There must be synchronization between common goals with the goals of each individual in the organization, 2) A pleasant social atmosphere is created, 3) The development of natural relationships between individuals in the process of daily interactions or interactions , 4) Be aware of the nature of individual differences, 5) Provide encouragement for the progress of each individual in an interaction, 6) Create an interesting atmosphere in the interaction process, 7) Must be able to respect other individuals if they interact in an activity, 8) Must be able to complement the need for the development of the process of interaction between individuals, 9) Respect each other's profession, 10) Give reasonable praise for the activities that have been carried out by others ${ }^{(11) .}$

The positive and significant influence between service quality and satisfaction on visiting behavior at the posyandu. Mother toddlers are also committed to informing the community about the experience of posyandu services, recommending their care experiences to others, promoting them to others, inviting others to visit the posyand $u$ and sharing positive experiences while receiving services at the posyandu. This is supported by Tjiptono's research which states that customer satisfaction is a customer commitment to a brand, store, supplier based on a very positive attitude and is reflected in consistent repeat purchases. Customer satisfaction that not only repurchases goods and services, but also has a positive commitment and attitude towards service companies, for example by recommending other people to buy ${ }^{(12)}$.

\section{CONCLUSION}

The quality of service and satisfaction of mothers under five have an effect on the behavior of mothers visiting "posyandu". Recommendation: if the quality of posyandu services is good, it will increase the satisfaction of mothers under five so that the behavior of visiting "posyandu" will increase.

\section{REFERENCES}

1. Dinkes Magetan. Profil Kesehatan Kabupaten Magetan Tahun 2017. Magetan: Dinkes Magetan; 2017.

2. Kemenkes RI. Hasil Utama Riset Kesehatan Dasar. Jakarta: Kemenkes RI. 2018.

3. Saepuddin E, Rizal E, Rusmana A. Posyandu Roles as Mothers and Child Health Information Center. Rec Libr J. 2018;3(2):201.

4. Kemenkes RI. Laporan Nasional Riset Kesehatan Dasar. Jakarta: Kemenkes RI: 2018.

5. Suharto A, Soedirham O, Dyson L. The Influence of Factors in Social Capital on the Behavior of Mothers to Visiting "Posyandu” Park. Dama International Journal of Researchers. 2016.

4| Publisher: Humanistic Network for Science and Technology 
6. Nursalam. Metodologi Penelitian. [Internet]. 2016. Available from: http://Eprints.Ners.Unair.Ac.Id/982/1/Metodologi Penelitian09162019.pdf

7. Etilidawati E, Handayani DY. Hubungan kualitas mutu pelayanan kesehatan dengan kepuasan pasien peserta jaminan kesehatan nasional. Medisains. 2017;15(3):142-7.

8. Hasnih., Gunawan. H. Pengaruh Lima Dimensi Kualitas Pelayanan PublikTerhadap Tingkat Kepuasan Masyarakat di Kelurahan Ompo Kecamatan Lalabata Kabupaten Soppeng. Mirai Manag. 2016;1(2):432.

9. Kuntoro W, Istiono W. Kepuasan Pasien Terhadap Kualitas Pelayanan di Tempat Pendaftaran Pasien Rawat Jalan Puskesmas Kretek Bantul Yogyakarta. J Kesehat Vokasional. 2017;2(1):140.

10. Almomani RZQ, Al-Ghdabi RR, Hamdan KM. Patients' satisfaction of health service quality in public hospitals: A PubHosQual analysis. Manag Sci Lett. 2020;10(8):1803-12.

11. Salehi A, Jannati A, Nosratnjad S, Heydari L. Factors influencing the inpatients satisfaction in public hospitals: a systematic review. Bali Med J. 2018;7(1):17.

12. Suharto A, Surtinah N, Puji TR. Cadre Behavior Model Independence To Improve The Early Detection of Children Growth And Development In The Posyandu Park District Magetan East Java of Indonesia. 